\title{
Urban renovation of the hot water supply system
}

\author{
Oleksandr Taraday ${ }^{1}$, Oleksandr Gvozdetskiy ${ }^{1 *}$, and Sergii Fomich ${ }^{1}$ \\ ${ }^{1}$ Kharkov National University of Civil Engineering and Architecture, Department of Heat and Gas \\ supply, Ventilation and Use of Thermal Secondary Energy Resources, Sumska str., 40, Kharkiv, \\ Ukraine, 61002.
}

\begin{abstract}
Issues related to improving the reliability of hot water supply systems are considered. Currently, centralized hot water supply systems are in an emergency condition due to the fact that the external networks are made of black pipes without anticorrosive coatings. A fundamental difference between hot water supply systems and heating systems is the nature of black metal corrosion. The purpose of this article is to conduct a research of the state of hot water supply systems and consider options for their recovery. The options suggested for restoration of hot water supply systems in cities and settlements of Ukraine are the following: complete replacement of failed networks with new pre-insulated plastic pipelines; refusal from external networks of centralized hot water supply systems and a central heat point with the installation of individual heat points in each house; decentralization of hot water supply systems by installing electric water heaters. A technical and economic comparison of these options is carried out, and the advantages and disadvantages of each option are considered. The arrangement of a set of individual heat points instead of one central point cannot be considered as the recommended method, because of the need for large additional costs for the reconstruction of heating, water supply and electricity supply systems. The most technically and economically justified method from the considered renovation methods of hot water supply systems is the complete replacement of failed steel pipelines with new nonmetallic pre-insulated structures.
\end{abstract}

\section{Introduction}

At present, most of centralized hot water supply systems of cities and settlements of Ukraine are in the state of failure due to the fact that the external pipework is made of black pipes, without any internal anticorrosive coatings. The main difference between hot water supply systems (HWSS) and heating systems is the nature of the black metal corrosion. In heating systems where chemically purified de-aerated water is circulating [1], mainly, external corrosion occurs due to various causes: stray currents, leaks from other systems and chemical composition of the soil [2-3]. More than $90 \%$ of the defects in the HWSS are resulted from internal corrosion [1-3]. Internal corrosion is caused by the chemical

\footnotetext{
${ }^{*}$ Corresponding author: npp-tghv@ukr.net
} 
composition of the heated under-aerated tap water and by air-blasting and, most importantly by the total lack of any protection of the internal pipe surface.

\section{The objective}

The objective of this article is to carry out the study of the state of hot water supply systems and consider options for their recovery.

\section{Matters of the article}

Table 1 is an example of the state of hot water supply piping. It shows the number of breakthroughs in the hot water pipelines in the city of Zaporozhye where vacuum deaeration is used to protect the inner pipelines surface [4-6].

Table 1. Failure rate of systems in 2005-2014.

\begin{tabular}{|c|c|c|c|c|c|c|c|c|c|c|c|c|c|c|}
\hline Boiler house & 2005 & 2006 & 2007 & 2008 & 2009 & 2010 & 2011 & 2012 & 2013 & 2014 & $\begin{array}{c}2005- \\
2014\end{array}$ \\
\hline \multicolumn{10}{|c|}{ double-pipeline system } \\
\hline $\begin{array}{c}\text { Sv.Nikolayastr., 79a } \\
\text { Shkolnayastr., 2a }\end{array}$ & 42 & 20 & 34 & 29 & 49 & 47 & 53 & 39 & 54 & 31 & 398 \\
\hline Nakhimova str., 4 & 78 & 37 & 94 & 85 & 91 & 134 & 111 & 122 & 113 & 88 & 953 \\
\hline \multicolumn{10}{|c|}{ four-pipeline system } \\
\hline Tovarischeskayastr., 47 & 15 & 12 & 16 & 20 & 19 & 20 & 21 & 19 & 17 & 22 & 181 \\
\hline Zadneprovskayastr., 7 & 18 & 13 & 13 & 16 & 19 & 32 & 29 & 37 & 39 & 28 & 244 \\
\hline Chubanovastr., 3d & 28 & 27 & 19 & 24 & 22 & 12 & 18 & 22 & 46 & 25 & 243 \\
\hline
\end{tabular}

It should be emphasized that the data given in Table 1 characterize the state of the hot water supply system of a large regional center, the only one in Ukraine where protection against internal corrosion is established. In other cities of Ukraine the number of "failures" is an order of magnitude greater. Despite excessive corrosion in some cities, including Kiev, centralized hot water supply continues to be implemented in Kharkov [7-9]. At the same time heating supply companies expend resources at times exceeding regulatory ones. This in turn leads to a tariffs increase. As the world experience shows centralized hot water supply systems can function normally only if they are made of galvanized, brass or nonmetallic pipes [9-11].

An important issue of reliable and economical operation of the hot water supply system is restoring circulation in the pipework. However, life requires the restoration of hot water supply in all cities and towns of Ukraine. We believe that the restoration of hot water supply is possible in several options.

The first option is a complete replacement of failed pipe networks with new preinsulated plastic pipelines.

The second option is the refusal of the existing external networks of a hot water supply system and central heat point (CHP) with installation of individual heat points (IHPs) in every house.

The third option is an installation of capacitive electric heaters in each apartment. 
In the first and second options funding is provided by municipalities and the state. In the third option funding is provided, mainly, by the apartment owners themselves.

When reasoned the second option it should be emphasized that the installation of several new IHPs for the preparation of hot water instead of one operating CHP is not a reasonable technical and economic decision. Calculation and practice show that hot water is more advantageous and easier to heat at a single location and fed through pipes to a group of buildings.

Some experts propose to replace one CHP by many IHPs. They justify their positions allegedly there is a need to install IHP everywhere in each house for heating needs. Due to this they as if "extend" the heating IHP giving it the function of preparing hot water. This presentation of the problem is not justified and correct. The installation of IHP, equipped with a variety of equipment, is not a necessity today neither from a technical point of view nor even from an economic point of view.

The question should be formulated clearly and unequivocally: how many installations for the preparation of hot water do we construct, one or several? The answer to this question is not unambiguous since it requires techno-economic justification.

Today we don't have to explore the matter of the rational number of CHPs for a micro district. The works of several authors gave an answer to this question in the eighties of the last century that it is more advantageous to have one CHP. Semicentennial practice of exploitation in Ukraine and other countries fully confirmed the theoretical development correctness of the past years.

Three options of heat supply systems for a micro district with twenty buildings with a total thermal load of $11.95 \mathrm{Gcal} / \mathrm{h}$, including $5.45 \mathrm{Gcal} / \mathrm{h}$ for hot water supply, are considered. Further we will carry out a techno-economic comparison of three options of renovating hot water systems.

The first option is a restoration of hot water supply through the complete replacement of all hot water pipelines and circulation pipelines, and external four-pipe heat networks of the micro district without sacrificing maintenance of the existing network configuration while maintaining the operating CHP.

Modern pre-insulated pipelines for hot water supply are ready-made for external noncanal laying structure in the form of straight or rolled up construction like "Isoproflex".
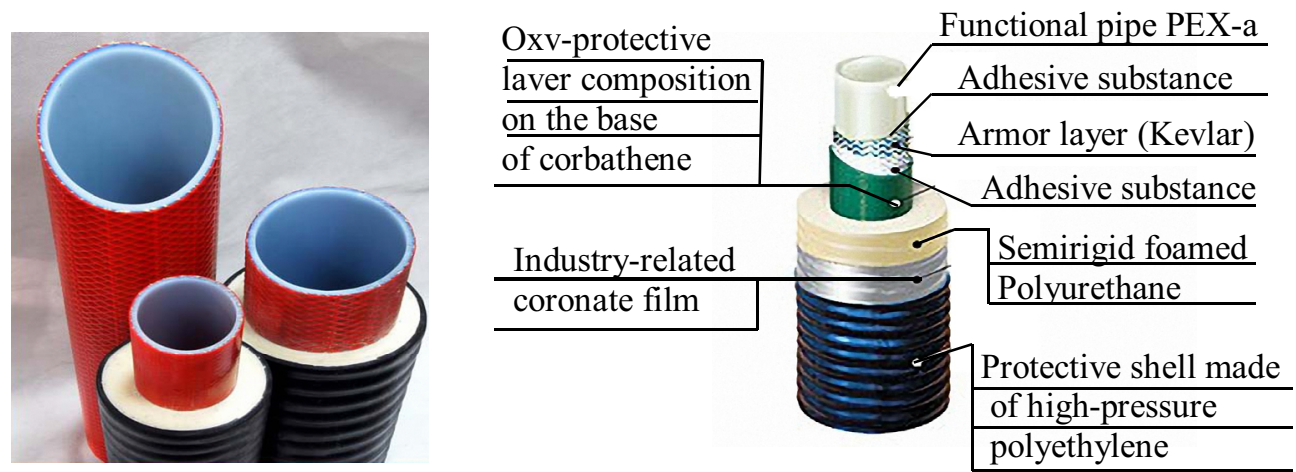

Fig.1. Pre-insulated pipe for hot water supply systems.

The laying of new pipelines is done on a non-canal principle using conduits in which the old networks of the hot water supply system were previously laid. In this case the conduits are filled with sand after dismantling the old pipes, and new pre-insulated pipelines are laid on a sand base, naturally, without any sliding supports. The matter of 
restoring conduits covering with slabs is decided in each individual case depending on the laying depth or the presence of a traffic way above the heating main.

Advantages of the first option:

- replacing only the external hot water supply networks we restore the efficiency of the entire system as heat exchange and pumping equipment at the CHP (TRS), as a rule, has kept its operability anywhere and does not require any replacement;

- preserving thermal load of hot water supply on the operating source of thermal energy, boiler house or CHPP.

Disadvantages of the first option:

- the need to break existing heating ducts; breaking and restoring road surfaces and lawns;

- dependence on hydraulic control and schedules of the heat supply company.

The second option. Instead of a single CHP preparation of hot water is provided at IHP in the basement of each building. At the same time the central heat point is virtually eliminated as an installation for the preparation of hot water.

The source of thermal energy for heating up hot water stays the same (CHPPor boiler house). Fig. 2 is a photograph of such IHP installed in the basement of a 16-storeyed residential building with a thermal load on heating and ventilation $-362,000 \mathrm{kcal} / \mathrm{h}$, on hot water supply - $297,000 \mathrm{kcal} / \mathrm{h}$.

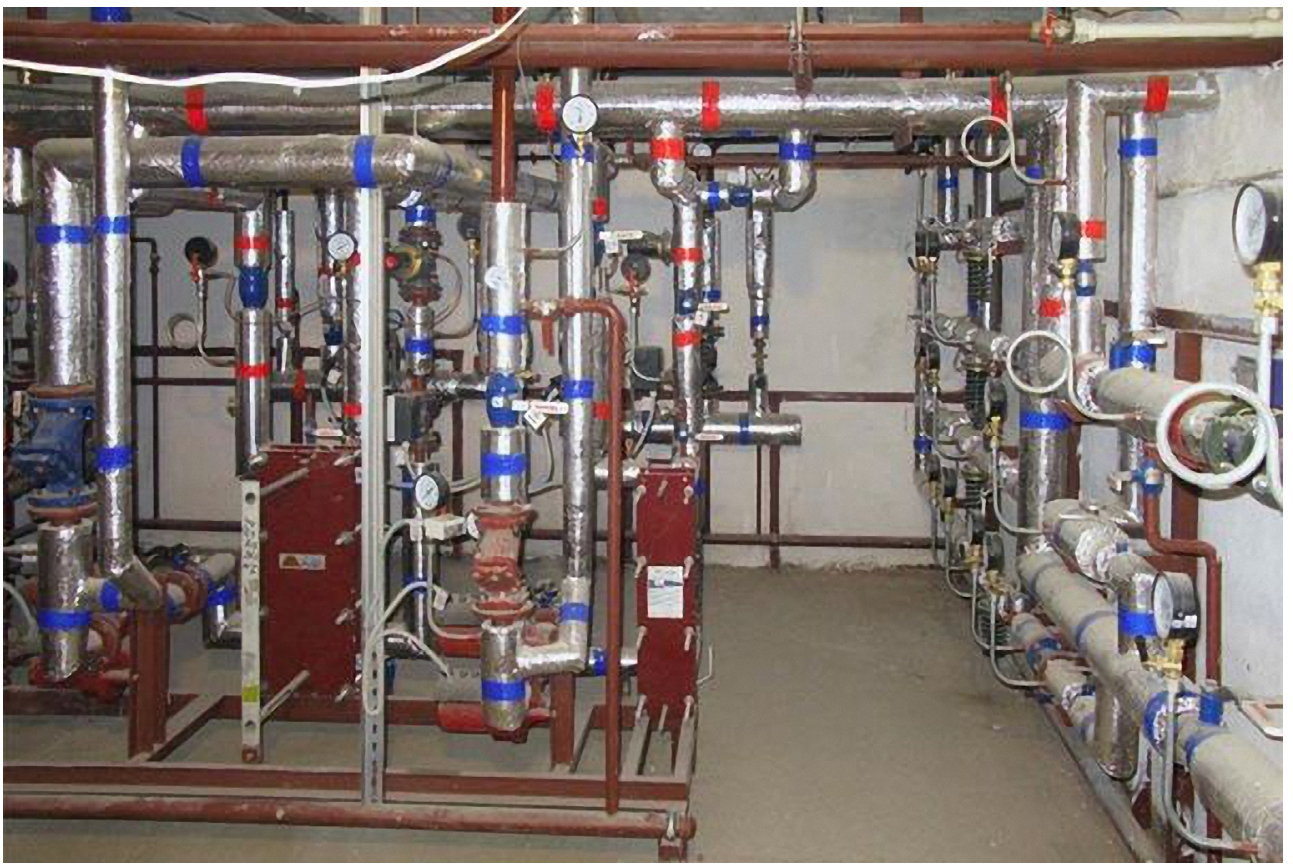

Fig. 2. Photograph of individual heat point in residential building.

Advantages of the second option:

-the possibility of preparing hot water for your own home regardless of other buildings in the micro district;

- cost reduction of the heat losses component by external heat networks in the price of hot water supply;

- thermal load conservation of hot water supply at the operating heat source: a boiler house or CHPP.

Disadvantages of the second option: 
- the need for capital input to construct a new individual heat point. For the 16-storeyed house considered above the costs are $430000 \mathrm{UAH}$;

- cost increase of the operating costs component in the price of hot water supply (additional personnel for servicing an individual heat point, and additional power costs for newly installed equipment);

-dependence on hydraulic control and schedules of a heat supply company;

- additional capital input for increasing the diameters of the existing submain heating networks due to a significant load increase on them related to the addition of a load on the HWS system. For example, prior to reconstruction thermal load delivered by the inlet and return pipeline at the entrance to the 16 -storeyed house was $362,000 \mathrm{kcal} / \mathrm{h}$. After reconstruction it is needed to start another $297,000 \mathrm{kcal} / \mathrm{h}$ along the same pipes, i.e. almost twice as much. At the same time, the load on all sections of the submain "heating" heating network increases to $84 \%$. For the main section the output load from the disconnected central heat point, which provides heat supply to 30 residential houses will be $11.95 \mathrm{Gcal} / \mathrm{h}$. instead of $6.5 \mathrm{Gcal} / \mathrm{h}$;

- diameters increase of the external cold water supply system;

- revision and partial reconstruction of the micro district power supply system due to the transfer of the location for heating up hot water from CHP to IHP installed in the basement of each house. boiler.

The third option. Preparation of water in each apartment by means of a mini electrical

Advantages of the third option:

- independence: hot water is always at the consumer's request;

- savings: consumer has full cost control of hot water supply;

- simplicity of installation and operation of the hot water preparation plant;

- apartment owners' self-solution about capital investments

- significant reduction of all operating costs for hot water in comparison with the first and second options.

Average costs per person per month we have calculated (with hot water allowance of 3 m3 per month) to pay for hot water supply at current tariffs in 2016 will be UAH 90 .

In the third option an advantage for the power supply company is that it acquires an additional consumer. Especially valuable and important for the power supply company is that the new consumer strives to expend electrical energy to heat up hot water at night, i.e. in the period of power consumption "valley value".

If to consider consumers changeover to independent apartment hot water supply as a trend in the development of the electric power industry, one can view this as a positive phenomenon in the future. Because the changeover to the direct electric water heating in the apartment gives a performance factor increase in the entire energy system by reducing losses when heating and transporting water heat-transfer fluids.

To drawbacks, and more correctly, to the expenses of the third option should be attributed:

- theelectricity supply company with the number of electric water heaters increasing should increase the build-up or redistribution of its capacities as well as to reconstruct domestic and outdoor networks and transformer substation;

- additional difficulties arise for water supply companies as they must ensure an almost twofold increase in cold water running supply to the apartment. Like in the second option they should perform the re-laying of external running water supply pipelines;

-in the case when the source of heat supply is a Central Heating and Power Plant (CHPP) there is mass disconnection of hot water consumers

- this is a decrease in its technical and economic indicators of the heat supply system as a whole. 
The main indicators for the three options are shown in Table 2.

Table 2. Reduced costs for $1 \mathrm{GCal}$ and the cost of $1 \mathrm{~m}^{3}$ of hot water.

\begin{tabular}{|c|c|c|c|c|}
\hline $\begin{array}{c}\text { Number } \\
\text { of option }\end{array}$ & Title & $\begin{array}{c}\text { Reduced } \\
\text { costs, UAH }\end{array}$ & $\begin{array}{c}\text { Cost of } 1 \mathrm{~m}^{3} \text { of hot } \\
\text { water per person }\end{array}$ & Source of funding \\
\hline I & $\begin{array}{c}\text { Complete replacement of } \\
\text { existing hot water supply } \\
\text { networks while } \\
\text { maintaining the CHP }\end{array}$ & 2560 & 120 & Municipality \\
\hline II & $\begin{array}{c}\text { Refusal of existing hot } \\
\text { water supply networks } \\
\text { and CHPs replacing them } \\
\text { with IHPs in each house }\end{array}$ & 3600 & 120 & $\begin{array}{c}\text { Municipality; } \\
\text { Electricity supply } \\
\text { company }\end{array}$ \\
\hline III & $\begin{array}{c}\text { Installation of electric } \\
\text { water heater in an } \\
\text { apartment }\end{array}$ & 2820 & 90 & $\begin{array}{c}\text { Apartment owner; } \\
\text { Municipality; } \\
\text { Electricity supply } \\
\text { company }\end{array}$ \\
\hline
\end{tabular}

\section{Conclusions}

-The use of black steel pipes for hot water supply, which is a gross violation of normative documents, led to massive damage to the pipelines of hot water systems caused by increased internal corrosion. The result of this approach is the almost complete cessation of centralized hot water supply in most cities and settlements of Ukraine.

-The only major regional city of Ukraine, where the centralized hot water supply system continues to operate normally enough, is the city of Zaporozhye. As everywhere it is made from black steel pipes without internal covering. Sufficient level of the central hot water supply system efficiency is ensured by using vacuum-aeration treatment of hot water to remove oxygen from it.

- Complete replacement of corroded pipelines with new non-metallic pre-insulated structures is a method which is the most technically and economically proved of the renovation methods of hot water supply systems considered above.

- Installation of a number of IHPs instead of a single CHP cannot be considered as a recommended method of mass renovation because of the need for heavy additional costs for the reconstruction of the entire heat supply system, water supply, and electricity supply partially.

- Changeover to apartment capacitive electric heaters is the most real and cost-efficient from the consumer's point of view. This method allows reanimating the hot water supply system in the shortest time, which is already being done everywhere in Ukraine.

-The use of the third method creates prerequisites for increasing the efficiency of power supply in the system, but leads to a decrease in technical and economic indicators of heat supply systems with a source of thermal energy - CHPP.

\section{References}

1. Yu.V. Balaban-Irmenin, V.I. Sharapov, A.M. Rubashov, Elektricheskie stantsii, 6, 4246 (1993)

2. A.A. Ionin, Reliability of the systems of thermal networks, M.: Stroyizdat, (1989)

3. V.M. Borovkov, V.G. Kiselev, Izvestiya RAN. «Energetik», 5, 110-119 (2006)

4. O.M. Taraday, S.V. Fomich, P.M. Glamazdin, Ventilyatsiya, osvitlennya ta teplogazopostachannya KNUBA, 19, 117-124 (2016) 
5. O.M. Taraday, M.O. Yaremenko, E.S. Esin, S.V. Fomich, Naukoviy visnik budivnitstva HNUBA, 83, 158-161 (2016)

6. O.M. Taraday, E.S. Esin, S.V. Fomich, N.S. Bolotskih, Naukoviy visnik budivnitstva HNUBA, 87, 188-191 (2017)

7. A.Ya. Naymanov, N.G. Nasonkina, V.N. Maslyak, N.I. Zolotov, Bases of reliability of the engineering systems of communal economy, Donetsk IEP NAN Ukraine (2001)

8. B.A. Permyakov, Yu.V. Kananovich, Economic and ecological comparison centralized and decentralized systems of teplosnabzheniya, M.: MGSU, (2002)

9. E.M. Malaya, S.A. Sergeeva, Novosti teplosnabzheniya, 4, 41-44 (2006).

10. O.F. Redko, O.M. Taraday, M.O. Yaremenko, I.G. Kirilenko, Naukoviy visnik budivnitstva HNUBA, 45, 233-236 (2008).

11. O.M. Taraday, O.F. Redko, I.G. Kirilenko, Naukoviy visnik budivnitstva HNUBA, 45, 128-132 (2008). 